\title{
Biological Testing
}

National Cancer Institute

\section{Source}

National Cancer Institute. Biological Testing. NCI Thesaurus. Code C18649.

Testing performed to determine the effects of substances upon living organisms. 